\title{
Considerations for the Care of Women with Gynecological Cancers during the COVID-19 Pandemic
}

\author{
Vinitha Reddy Palwai ${ }^{1} \quad$ Monica Irukulla ${ }^{2}$ \\ ${ }^{1}$ Department of Radiation Oncology, AIG Hospitals, Gachibowli, \\ Hyderabad, Telangana, India \\ 2Department of Radiation Oncology, Nizam's Institute of Medical \\ Sciences, Hyderabad, Telangana, India
}

\author{
Address for correspondence Dr. Monica Irukulla, MD, Department \\ of Radiation Oncology, Nizam's Institute of Medical Sciences, \\ Hyderabad, Telangana, India (e-mail: dr_monica11@yahoo.com).
}

Ind J Car Dis Wom:2020;5:256-259

\begin{abstract}
Keywords

- gynecological cancers

- COVID-19

- pandemic

- guidelines

Delivering care for patients with cancer during the COVID-19 pandemic can pose a significant challenge, given the fact that cancer patients face a higher risk of morbidity and mortality from the infection. Outcomes in gynecological cancers are heavily stage-dependent, ranging from 5 -year survival $95 \%$ in early stage to less than $15 \%$ in advanced stages. Early diagnosis and timely treatment are therefore of the utmost importance, but they should be balanced, considering the availability of local expertise and resources and the local pandemic status. This article outlines the management guidelines for the care of women with gynecological malignancies during the COVID-19 pandemic.
\end{abstract}

\section{Introduction}

The COVID-19 pandemic has resulted in unprecedented disruption of cancer care throughout the world. Cancer patients are faced with the dual risk of acquiring potentially more severe COVID-19 infection versus compromised oncological outcomes, resulting from delay in cancer care.

An analysis of 218 patients with cancer who were diagnosed with COVID-19 in New York showed that patients who acquired COVID-19 had a significantly higher morbidity and mortality compared with age-adjusted patients without cancer.

There are studies that document the pandemic-affected scenario and changes in gynecological and other womenrelated cancer care as well as perception of oncologists. ${ }^{2}$ Digital technology is being increasingly adopted, both for patient care and educational activities to maintain continuity of care and training of students and residents.

Planning the management for patients with cancer during the pandemic should consider the higher risk of morbidity and mortality from the infection in cancer patients who may be suffering from other comorbidities and could be immunocompromised. However, it is important to avoid undue delays that can compromise outcomes. Many patients with cancer are struggling to receive treatment for their cancers due to hospitals cancelling or delaying surgeries and other procedures, including chemotherapy and radiation therapy. Besides, strict lockdowns and lack of public transportation has made access to cancer care prohibitive for many patients. ${ }^{3}$

\section{COVID-19 and Gynecological Cancers}

Women in developing countries are an especially vulnerable group whose healthcare needs are often neglected. Outcomes in gynecological cancers are heavily stage-dependent, ranging from 5-year survival $95 \%$ in early stage to less than $15 \%$ in advanced stages. Early diagnosis and timely treatment is therefore of the utmost importance.

Performance of extensive surgical procedures in the COVID-19 era can be risky for both patients and healthcare workers. There is a high risk of postoperative complications in patients with asymptomatic COVID-19 infection. Hence, the importance of preoperative triage to identify patients harboring COVID-19 is paramount. Patients should be screened for symptoms suspicious of COVID-19, including fever, respiratory symptoms, etc. or a history of exposure to COVID-19 cases in the preceding two weeks. Many centers have
(C)2020 Women in Cardiology and Related Sciences
License terms

(ㅇ)( $\Theta \circledast$ 
incorporated a CT scan of the chest and a nasopharyngeal swab in the presurgical evaluation protocols. ${ }^{4}$ It is also prudent to avoid or postpone all nonurgent surgical procedures till the pandemic wanes. Hanna et al have proposed a conceptual framework which offers guidance on prioritization of care of cancer patients during the pandemic. ${ }^{5}$ Prioritizing should consider the availability of resources, the intent of treatment, and the magnitude of potential benefit from any intervention. Other considerations include effects of interruptions or delays on outcomes, the patient's performance status and socioeconomic status, and availability of infrastructure and expertise.

The European Society of Medical Oncology (ESMO) ${ }^{6}$ and various other oncological societies have proposed a tiered approach to guide clinical decision-making in oncological care during the COVID-19 pandemic. It has been formulated across three levels of priorities, devised to inform the urgency of any intervention across various clinical scenarios. Tier 1 refers to high-priority indications which require urgent intervention, Tier 2 refers to medium-priority situations where a short delay may be justified, depending on the risk versus benefit, and Tier 3 implies low-priority interventions which can be safely deferred till the pandemic subsides. These tiers have been defined according to the criteria of the Cancer Care Ontario guidelines. ${ }^{7}$ The Asian Society of Gynecologic Oncology and Korean Society of Gynecologic Oncology have proposed a set of guidelines for gynecologic cancer care during the COVID 19 pandemic $^{8}$ ( - Table 1), with priorities designated as $\mathrm{A}, \mathrm{B}$ and $\mathrm{C}$, where $\mathrm{A}$ represents the highest priority and $C$ the lowest.

\section{Cervical Cancer Care (- Table 2)}

Cervical cancer being a relatively aggressive malignancy, with a good potential for cure in early stages, should be treated without delay even in the midst of the pandemic. All routine screening procedures should be suspended and evaluation of low-grade intraepithelial lesions may be postponed. ${ }^{8,9}$ Radiotherapy and concomitant chemotherapy should be the preferred first-line treatment, and radical surgery should be avoided whenever possible. Hysterectomy after chemoradiation has no proven benefit and should be reserved only for cases in which postradiation residual disease is identified. In case surgery is planned, consideration should be given to avoiding procedures with long operative times, or those with a higher potential intra and/or postoperative complications. It is preferable to defer planned

Table 1 Classification of priorities according to the severity of the disease condition ${ }^{7}$

\begin{tabular}{|l|l|}
\hline Priority & Severity of disease \\
\hline A & Life-threatening, needs emergency care \\
\hline B & $\begin{array}{l}\text { Nonlife threatening and could be deferred } \\
\text { for 6-8 weeks }\end{array}$ \\
\hline C & $\begin{array}{l}\text { Stable, treatment may be discontinued during the } \\
\text { COVID-19 pandemic }\end{array}$ \\
\hline
\end{tabular}

Table 2 Guidelines for care of patients with cervical cancer during the COVID-19 pandemic

\begin{tabular}{|c|c|c|}
\hline Priority & Clinical status & Recommendation \\
\hline \multicolumn{3}{|c|}{ Newly diagnosed disease } \\
\hline A & Recently diagnosed & $\begin{array}{l}\text { Diagnostic and staging workup } \\
\text { should be performed without } \\
\text { delay, based on the local } \\
\text { COVID-19 situation }\end{array}$ \\
\hline A & $\begin{array}{l}\text { Severe/massive } \\
\text { vaginal bleeding }\end{array}$ & $\begin{array}{l}\text { Diagnostic workup should } \\
\text { be performed without delay. } \\
\text { Necessary measures should be } \\
\text { instituted without delay }\end{array}$ \\
\hline C & Routine screening & Should be discontinued \\
\hline \multicolumn{3}{|c|}{ Abnormal cytology } \\
\hline B & $\begin{array}{l}\text { Low-grade } \\
\text { intraepithelial lesion }\end{array}$ & $\begin{array}{l}\text { Further assessment may be } \\
\text { deferred for } 6-12 \text { months }\end{array}$ \\
\hline B & $\begin{array}{l}\text { High-grade } \\
\text { intraepithelial lesion }\end{array}$ & $\begin{array}{l}\text { Should be evaluated preferably } \\
\text { within } 3 \text { months }\end{array}$ \\
\hline B & Invasive cancer & $\begin{array}{l}\text { Diagnostic workup should be } \\
\text { done within } 2 \text { weeks }\end{array}$ \\
\hline \multicolumn{3}{|c|}{ Invasive disease } \\
\hline C & $\begin{array}{l}\text { Stage IA1 (following } \\
\text { excision/ablation } \\
\text { procedures) }\end{array}$ & $\begin{array}{l}\text { Observation until the pandemic } \\
\text { subsides }\end{array}$ \\
\hline B & $\begin{array}{l}\text { Stage IA2 (following } \\
\text { excision/ablation } \\
\text { procedures) }\end{array}$ & $\begin{array}{l}\text { Treatment may be deffered } \\
\text { for } 6-8 \text { weeks }\end{array}$ \\
\hline B & Stage IB1, IB2, IIA1 & $\begin{array}{l}\text { Surgery may be deferred } \\
\text { for } 6-8 \text { weeks. Alternatively, CRT } \\
\text { may be offered }\end{array}$ \\
\hline B & $\begin{array}{l}\text { Stage IB3, IIA2, III, } \\
\text { IVA }\end{array}$ & $\begin{array}{l}\text { Should be treated with CRT and } \\
\text { brachytherapy without delay }\end{array}$ \\
\hline C & $\begin{array}{l}\text { Postoperative } \\
\text { with low risk of } \\
\text { recurrence }\end{array}$ & Observation \\
\hline B & $\begin{array}{l}\text { Postoperative } \\
\text { with high risk of } \\
\text { recurrence }\end{array}$ & CRT on schedule \\
\hline B & Stage IVB & $\begin{array}{l}\text { Systemic chemotherapy }+1- \\
\text { palliative radiation }\end{array}$ \\
\hline
\end{tabular}

Abbreviation: CRT, chemoradiotherapy.

radical surgery for a period of 6 to 8 weeks, or until the pandemic mitigates. ${ }^{8} 9$ Hypofractionation schedules should be considered, whenever feasible, and brachytherapy should not be delayed. All measures should be taken to ensure that the entire treatment is completed within 8 weeks, as prolonged overall treatment times are associated with inferior outcomes. Adjuvant radiation may be deferred by up to 8 to 12 weeks if necessary, depending on the clinical scenario. ${ }^{10}$

\section{Endometrial Cancer Care (- Table 3)}

Care of these patients may be based on risk stratification criteria. Patients with low-grade disease deemed as low risk can be considered for hormonal therapy strategies like oral progestins or intrauterine devices (IUDs). Surgery should not be delayed in high-risk patients with active bleeding. 
Table 3 Care of patients with endometrial cancer during COVID-19 pandemic

\begin{tabular}{|c|c|c|}
\hline Priority & $\begin{array}{l}\text { Clinical } \\
\text { status }\end{array}$ & Recommendation \\
\hline A & $\begin{array}{l}\text { Abnormal } \\
\text { uterine } \\
\text { bleeding with } \\
\text { suspicious } \\
\text { intrauterine } \\
\text { pathology } \\
\text { on TVUS }\end{array}$ & $\begin{array}{l}\text { Endometrial biopsy should be done } \\
\text { without delay }\end{array}$ \\
\hline B & $\begin{array}{l}\text { Premalignant } \\
\text { disease }\end{array}$ & $\begin{array}{l}\text { If fertility preservation desired, } \\
\text { conservative measures like oral } \\
\text { progestins/IUD } \\
\text { In all other cases, simple hyster- } \\
\text { ectomy may be deferred for up to } \\
8 \text { weeks }\end{array}$ \\
\hline A & Invasive cancer & $\begin{array}{l}\text { Surgical staging should be done } \\
\text { without delay in patients with } \\
\text { active bleeding. Can be deferred } \\
\text { for up to } 8 \text { weeks in patients } \\
\text { without active bleeding }\end{array}$ \\
\hline C & $\begin{array}{l}\text { Surgically } \\
\text { staged Low } \\
\text { risk stage I/II } \\
\text { disease }\end{array}$ & Observation \\
\hline B & $\begin{array}{l}\text { Surgically } \\
\text { staged } \\
\text { Intermediate } \\
\text { risk stage } 1 / \text { II } \\
\text { disease }\end{array}$ & Brachytherapy alone (preferred) \\
\hline B & $\begin{array}{l}\text { Surgically } \\
\text { staged } \\
\text { high-risk stage } \\
\text { I/II/III/IVA } \\
\text { disease }\end{array}$ & $\begin{array}{l}\text { Adjuvant radiation }+ \text { / - } \\
\text { chemotherapy }\end{array}$ \\
\hline B & $\begin{array}{l}\text { Inoperable } \\
\text { stage III/IVA } \\
\text { and stage IVB } \\
\text { disease }\end{array}$ & $\begin{array}{l}\text { Systemic chemotherapy. Use } \\
\text { regimens which will avoid frequent } \\
\text { patient visits }\end{array}$ \\
\hline C & $\begin{array}{l}\text { Posttreatment } \\
\text { follow-up }\end{array}$ & $\begin{array}{l}\text { Can be deferred till the pandemic } \\
\text { subsides }\end{array}$ \\
\hline
\end{tabular}

Abbreviation: IUD, intrauterine device; TVUS, transvaginal ultrasound.

A short delay of less than 8 weeks can be considered in patients with clinically early disease without active bleeding. The preferred approach in patients with higher grade tumors (grade 2 or 3 ) or high-risk histologies is a simple hysterectomy with bilateral salpingo-oophorectomy. Decisions regarding lymph node dissection should be individualized based on risk status, since this will prolong the duration of surgery. If available sentinel lymph node sampling is preferred. Decisions regarding adjuvant therapy should be based on risk stratification. Patients with clinically advanced tumors should be considered for a tissue biopsy to confirm diagnosis followed by systemic therapy. ${ }^{8,9}$ Patients with endometrioid histology can be considered for hormonal therapy, if necessary, and radiation can be deferred. ${ }^{10}$ Following surgery, adjuvant radiation therapy can be delayed between 6 to 8 weeks..$^{10}$ It may be prudent to reduce the number of radiotherapy fractions and/or whenever deemed necessary, use chemotherapy judiciously,
Table 4 Care of patients with epithelial ovarian cancer during the COVID-19 pandemic

\begin{tabular}{|c|c|c|}
\hline Priority & Clinical status & Recommendation \\
\hline A & $\begin{array}{l}\text { Suspected ovarian } \\
\text { cancer with major } \\
\text { symptoms such as } \\
\text { perforation, obstruc- } \\
\text { tion, massive ascites } \\
\text { or peritonitis }\end{array}$ & $\begin{array}{l}\text { Assessment and necessary } \\
\text { measures should be under- } \\
\text { taken without delay }\end{array}$ \\
\hline B & $\begin{array}{l}\text { Suspected early stage } \\
\text { disease confined to } \\
\text { pelvis }\end{array}$ & $\begin{array}{l}\text { Surgical staging may be } \\
\text { deferred for 6-8 weeks }\end{array}$ \\
\hline B & $\begin{array}{l}\text { Disease extending } \\
\text { beyond pelvis }\end{array}$ & $\begin{array}{l}\text { Neoadjuvant } \\
\text { chemotherapy 3-6 cycles. } \\
\text { Interval cytoreduction may } \\
\text { be performed after } 6 \text { cycles } \\
\text { Chemotherapy regimens } \\
\text { should be chosen to mini- } \\
\text { mize patient visits }\end{array}$ \\
\hline A & $\begin{array}{l}\text { Suspected postoper- } \\
\text { ative complications } \\
\text { (bleeding/perforation/ } \\
\text { infection, etc.) }\end{array}$ & $\begin{array}{l}\text { Should be addressed } \\
\text { without delay }\end{array}$ \\
\hline A & $\begin{array}{l}\text { Surgically staged dis- } \\
\text { ease with high grade } \\
\text { endometrioid/serous } \\
\text { histology }\end{array}$ & $\begin{array}{l}\text { Adjuvant chemotherapy } \\
\text { should not be delayed }\end{array}$ \\
\hline C & Low-grade histology & $\begin{array}{l}\text { Adjuvant chemotherapy } \\
\text { may be avoided }\end{array}$ \\
\hline B & $\begin{array}{l}\text { Nonhigh-grade } \\
\text { serous/endometrioid, } \\
\text { clear cell or mucinous } \\
\text { histology }\end{array}$ & $\begin{array}{l}\text { Adjuvant chemotherapy } \\
\text { may be less beneficial. Can } \\
\text { be offered after discus- } \\
\text { sion of risk versus benefit. } \\
\text { Consideration should be } \\
\text { given to minimizing toxicity } \\
\text { and patient visits }\end{array}$ \\
\hline C & $\begin{array}{l}\text { Posttreatment } \\
\text { follow-up }\end{array}$ & $\begin{array}{l}\text { Can be postponed in } \\
\text { low-risk cases. }\end{array}$ \\
\hline C & $\begin{array}{l}\text { Patients of mainte- } \\
\text { nance therapies }\end{array}$ & $\begin{array}{l}\text { Minimize patient visits. } \\
\text { Telemedicine monitoring } \\
\text { preferred }\end{array}$ \\
\hline $\mathrm{B} / \mathrm{C}$ & Recurrent disease & $\begin{array}{l}\text { Management should be } \\
\text { individualized, based on } \\
\text { clinical status, risk factors, } \\
\text { and local conditions }\end{array}$ \\
\hline
\end{tabular}

preferring regimens which are less toxic, and avoid frequent patient visits.

\section{Epithelial Ovarian Cancer Care (-Table 4$)^{8}$}

In suspected early ovarian cancer, clinical decision-making should consider multiple factors such as age, performance status, comorbidities, and family history. Physical examination and a thorough diagnostic workup comprising abdominal ultrasound with color Doppler, CECT/MRI, and/or serum markers such as CA125 and HE4 should be done. ${ }^{9}$ In suspected early stage ovarian cancer, surgery is considered mandatory and includes hysterectomy, bilateral salpingo-oophorectomy, and peritoneal staging. Lymphadenectomy may be avoided due to its uncertain benefit. It can be considered in cases where nodal status would be helpful to make decisions 
regarding adjuvant chemotherapy. Procedures such as hyperthermic intraperitoneal chemotherapy (HIPEC) should be avoided during the COVID-19 pandemic. ${ }^{4}$

In patients with advanced stage disease, tissue biopsy should be done to confirm the diagnosis, and neoadjuvant chemotherapy and delayed surgery is a reasonable approach, given the risks of extensive surgical procedures during the pandemic. In patients already on neoadjuvant chemotherapy, extending the plan to six cycles, rather than three, before interval cytoreductive surgery can be considered, depending on resource availability, feasibility of surgery and institutional management protocols; recognizing additional chemotherapy can deplete the bone marrow reserve and cause immunosuppression. ${ }^{8,9,4}$

Maintenance therapy may be withheld after completion of platinum-based adjuvant chemotherapy, since repeat visits may place additional risk of infection on the patient, families, and healthcare teams. ${ }^{9}$ Patients with ovarian cancer should, as far as possible, be treated in COVID-19 free specialized healthcare facilities. In patients with active infection, active oncological treatments should be deferred until full recovery. In general, extensive surgical procedures should be avoided during the outbreak. ${ }^{4}$

\section{Cancers of Vagina and Vulva}

These cancers are relatively less common and should be treated judiciously with surgery or radiation + -chemotherapy, depending on patient age, comorbidities, stage of disease, and other risk factors. Local factors and the relative risk versus benefit for treatment delays needs to be considered.

\section{Summary}

Gynecological cancers are associated with high-cure rates, especially in early stages; hence, every effort should be made to provide timely treatment while minimizing the pandemic-related risks. A judicious modification of treatment protocols is warranted. The recommendations provided by various societies and institutes serve as general guidelines and need to be considered in the light of local circumstances and protocols, which may be constantly changing as the pandemic continues to evolve.

\section{Source of Funding}

Nil.

\section{Conflicts of Interest}

None declared.

\section{References}

1 Mehta V, Goel S, Kabarriti R, et al. Case fatality rate of cancer patients with COVID-19 in a New York hospital system. Cancer Discov 2020;10(7):935-941

2 Martinelli F, Garbi A. Change in practice in gynecologic oncology during the COVID-19 pandemic: a social media survey. Int J Gynecol Cancer 2020;30(8):1101-1107

3 De Guzman R, Malik M. Dual challenge of cancer and COVID-19: impact on health care and socioeconomic systems in Asia Pacific. JCO Glob Oncol 2020;6:906-912

4 Bogani G, Casarin J, Pinelli C, et al. Management of patients with ovarian cancer in the COVID-19 era. J Surg Oncol 2020;122(2):122-123

5 Hanna TP, Evans GA, Booth CM. Cancer, COVID-19 and the precautionary principle: prioritizing treatment during a global pandemic. Nat Rev Clin Oncol 2020;17(5):268-270

6 ESMO Management and Treatment Adapted Recommendations In The COVID-19 Era: Cervical Cancer. Available at: https:// www.esmo.org/guidelines/cancer-patient-managementduring-the-covid-19-pandemic/gynaecological-malignanciescervical-cancer-in-the-covid-19-era. Accessed August 24, 2020

7 Pandemic Planning Clinical Guideline for Patients With Cancer Available at: https://www.accc-cancer.org/docs/documents/cancer-program-fundamentals/oh-cco-pandemicplanning-clinical-guideline_final_2020-03-10.pdf. Accessed August 24, 2020

8 [No authors listed]. Recommendations for gynecologic cancer care during the COVID-19 pandemic. J Gynecol Oncol 2020;31(4):e6910.3802/jgo.2020.31.e69

9 Ramirez PT, Chiva L, Eriksson AGZ, et al. COVID-19 global pandemic: options for management of gynecologic cancers. Int J Gynecol Cancer 2020;30(5):561-563

10 Elledge CR, Beriwal S, Chargari C, et al. Radiation therapy for gynecologic malignancies during the COVID-19 pandemic: International expert consensus recommendations. Gynecol Oncol 2020;158(2):244-253 